\title{
Calculation of temperature distribution and rheological properties of the lithosphere along transect IV in the Western Carpathian-Pannonian Basin region
}

\author{
Jana DÉREROVÁ ${ }^{1, *}$, Miroslav BIELIK ${ }^{1,2}$, Igor KOHÚT ${ }^{1}$, \\ Dominika GODOVÁ ${ }^{1}$ \\ ${ }^{1}$ Division of Geophysics, Earth Science Institute of the Slovak Academy of Sciences, \\ Dúbravská cesta 9, 84005 Bratislava, Slovak Republic \\ ${ }^{2}$ Department of Applied and Environmental Geophysics, Faculty of Natural Sciences, \\ Comenius University, Mlynská dolina, Ilkovičova 6, 84248 Bratislava, Slovak Republic
}

\begin{abstract}
D integrated modelling algorithm was used to calculate the temperature distribution in the lithosphere along the transect IV located in the Western CarpathianPannonian Basin area. Based on the determined temperature field and given rheological parameters of the rocks, it was possible to calculate the strength distribution for both compressional and extensional regimes, construct the strength envelopes for chosen columns of the main tectonic units of the model, and thus construct a simple rheological model of the lithosphere along transect IV. The obtained results indicate decrease of the lithospheric strength from the European platform and the Western Carpathians towards the Pannonian Basin. The largest strength (valid for all tectonic units) can be observed within the upper crust with its maxima on the boundary between upper and lower crust, decreasing towards lower crust and disappearing in the lithospheric mantle, suggesting mostly rigid deformation occurring in the upper crust. A local increase in the values of strength can be observed in the eastern segment of the Western Carpathians where crustal thickening accompanies the lithospheric thickening (formation of the lithospheric root), unlike the previous models along transects I and II, that pass through the western segment of the Western Carpathians and their lithosphere-asthenosphere boundary is almost flat and therefore no accompanying crustal thickening is observed and the decrease in strength is slow and steady.
\end{abstract}

Key words: 2D integrated modelling, temperature field, rheological parameters, compressional and extensional strength, strength envelopes

\footnotetext{
*corresponding author: e-mail: geofjade@savba.sk
} 


\section{Introduction}

The Carpathian-Pannonian Basin region together with its surrounding tectonic units is a very complex lithospheric system where many different tectonic units can be identified in a relatively small area. Therefore, it provides a great opportunity to study their mutual interactions, the interaction of lithosphere and asthenosphere as well as many geodynamic interactions within the lithosphere during volcanic arc and related fore- and back-arc basin development.

The Pannonian Basin is young and hot, while the Western Carpathians, although being young as well, are colder. The evolution of the Carpathian arc was driven by the inter-related processes of rift genesis, crustal thinning, lateral displacement, rotational movements, convergence, collisional suturing, accretion, transpressive-transtensive subduction, slab rollback, asthenospheric up-welling and lateral extrusion of the Eastern Alps and Dinarides-Balkan orogens, while formation of the Pannonian Basin is related to interplay of contraction, strike-slip and extension (Ratschbacher et al., 1991a,b; Csontos et al., 1992; Horváth, 1993).

The Carpathian-Pannonian Basin region has been covered by extensive geophysical surveys, and an enormous amount of geological and geophysical data such as deep seismic reflection and refractions data (Mayerová et al., 1994; Tomek et al., 1989; Vozár and Šantavý, 1999), gravity data (Bielik et al.,2006; Alasonati Tašárová et al., 2009; Zahorec et al., 2013), surface heat flow data (Čermák et al., 1991; Majcin, 1993), geoelectric data (Putiška et al., 2012a,b), magnetotelluric data (Ádám, 1996) has been collected and is available for calculations and modelling in order to reconstruct the structure of the lithosphere and geodynamical and tectonic processes within it. Despite the fact that the Carpathian-Pannonian Basin area becomes very well explored and studied, the main focus still lays on the lithospheric structure reconstruction (Alasonati Tašárová et al., 2009, 2016; Grinč et al., 2013; Hrubcová et al., 2010; Dérerová et al., 2006; Grad et al., 2006; Bielik et al., 2005 and many others). We believe that rheological modelling can provide additional information to already existing lithosperic models and contribute to better understanding of interactions among different tectonic units from rheological point of view.

The very first rheological models of the lithosphere have been calculated 
by Bielik and Striženec (1994), Bielik and Ursiny (1997) and Lankreijer et al. (1999). 2-dimensional integrated modelling method has been used to calculate temperature distribution and construct the rheological model along transect I (Dérerová et al., 2012) and and transect II (Dérerová et al., 2014) passing through the Carpathian-Pannonian basin region. To improve the rheological model of the lithosphere in the study area, we decided to continue in our approach and calculate and construct rheological model along transect IV located in the same study area.

\section{The Western Carpathian Transect IV}

The studied transect IV (Zeyen et al., 2002) (Fig. 1) starts in the Polish European foreland, continues across the Western Carpathian molasse foredeep, the Outer Western Carpathian flysch, the Pienniny Klippen Belt, the Slovenské Rudohorie Mts. and finishes in the Pannonian Basin. From an interpretation point of view the direction of the transect IV is not optimal, since it is not perpendicular to the strike of the geological structures. We chose this profile nevertheless because it coincides with the international transect CEL04, which is one of the seismic profiles of the CELEBRATION 2000 project. Its length is $550 \mathrm{~km}$ and the layout of main geological structures it consists of can be seen on Fig. 2 (Zeyen et al., 2002).

\section{Method}

Lithospheric structure along Transect IV (Fig. 2) has previously been modelled as a part of a tectonic and geodynamical reconstruction of the Western Carpathians-Pannonian basin region (Zeyen et al., 2002), using 2D integrated geophysical modelling method. It is an algorithm that calculates lithospheric thermal structure based on the simultaneous interpretation of surface heat flow, gravity, and topography data. A finite element algorithm is used to calculate the two-dimensional temperature distribution in the lithosphere, given its thickness (here defined as the $1300{ }^{\circ} \mathrm{C}$ isotherm) and the distribution of heat production and thermal conductivity, solving the steady state heat conduction equation (Lachenbruch and Sass, 1977):

$\lambda \nabla^{2} T=A$, 


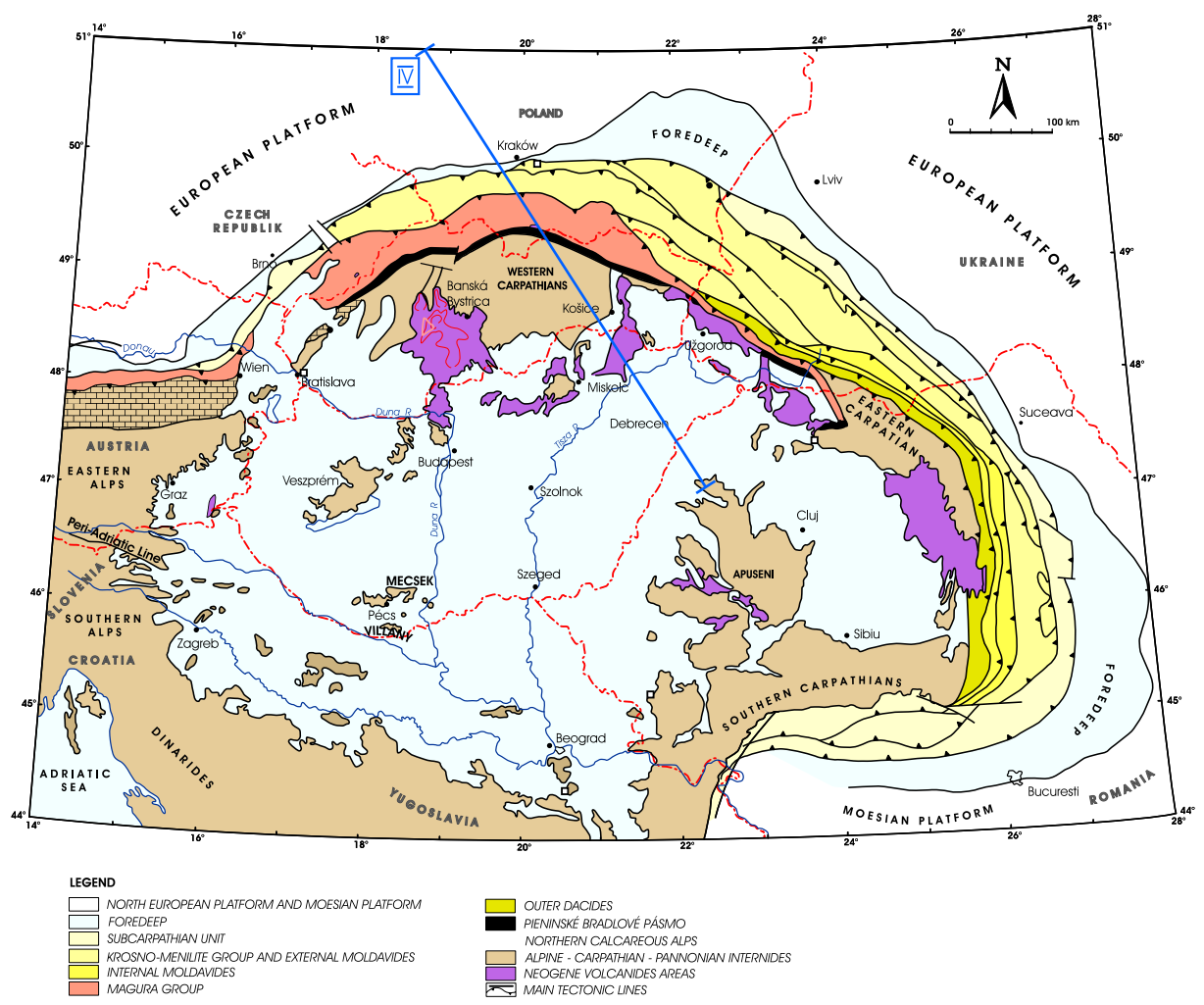

Fig. 1. Location of transect IV on the map of the Carpathian-Pannonian Basin region (modified after Zeyen et al., 2002).

where $\lambda$ is the thermal conductivity $\left[\mathrm{Wm}^{-1} \mathrm{~K}^{-1}\right], T$ is the temperature $[\mathrm{K}]$ and $A$ the heat production $\left[\mathrm{Wm}^{-3}\right]$. More detailed description can be found in Zeyen and Fernàndez (1994).

Based on the determined temperature distribution in the lithosphere, we can calculate the yield strength for a given distribution of rheological rock parameters. The strength is defined as the minimum of brittle and ductile strength at each point. For brittle strength calculation we have assumed that deformation occurs according to the frictional sliding law given by Byerlee (1978):

$\sigma_{\text {brittle }}=\alpha \rho g z(1-\lambda)$,

where $\sigma_{\text {brittle }}$ is brittle failure function [Pa], parameter $\alpha=R-1 / R$ is valid 


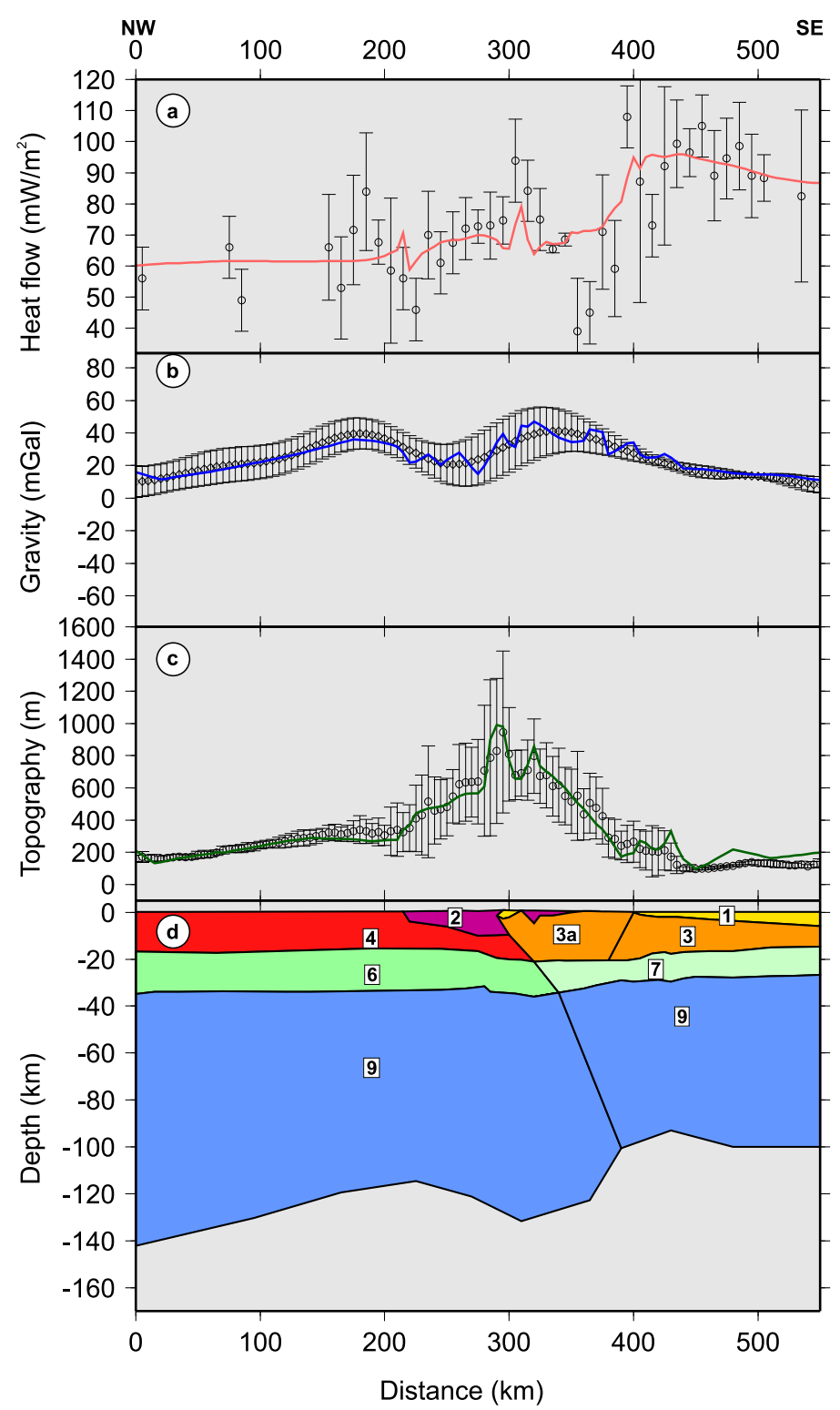

Fig. 2. Lithospheric model along transect IV. (a) Surface heatflow, (b) free air gravity anomaly, (c) topography with dots corresponding to measured data with uncertainty bars and solid lines to calculated values. Numbers in (d) correspond to material number in Table 1b (Zeyen et al., 2002). 
for normal faulting, $\alpha=R-1$ for thrust faulting, $\alpha=R-1 /[1+\beta(R-1)]$ for strike-slip faulting. Parameter $R=\left[\left(1+f_{s}^{2}\right)^{1 / 2}-f_{s}\right]^{-2}$ depends on coefficient of static friction $f_{s}, \lambda$ represents the hydrostatic pore fluid factor, $\rho$ is material density $\left[\mathrm{kg} \mathrm{m}^{-3}\right], g$ is acceleration of gravity $\left[\mathrm{m} \mathrm{s}^{-2}\right], z$ is depth $[\mathrm{m}], \beta$ is extension factor.

Ductile strength is calculated assuming power-law creep deformation given as (Lynch and Morgan, 1987):

$\sigma_{\text {creep }}=\left(\frac{\dot{\varepsilon}}{A_{p}}\right)^{1 / n} \exp \left[\frac{E_{p}}{n R T}\right]$,

where $\sigma_{\text {creep }}$ is power law creep function $[\mathrm{Pa}], \dot{\varepsilon}$ denotes strain rate $\left[\mathrm{s}^{-1}\right], A_{p}$ is Dorn constant, $n$ is power law exponent, $E_{p}$ is power law activation energy $\left[\mathrm{kJ} \mathrm{mol}^{-1}\right], R$ is universal gas constant $\left[8.314 \mathrm{~J} \mathrm{~mol}^{-1} \mathrm{~K}^{-1}\right], T$ is temperature $[\mathrm{K}]$.

\section{Results}

2D integrated modelling algorithm has been used to calculate temperature distribution for a pre-modelled lithospheric structure of the transect IV (Fig. 3). The lower limit of the model corresponds to $1300{ }^{\circ} \mathrm{C}$ isotherm which represents the lithosphere-asthenosphere boundary in geotermics. On the surface (the upper boundary of the temperature model), the temperature $20^{\circ} \mathrm{C}$ has been considered. The temperature distribution has been calculated for every node of the model. Temperature field reflects the distribution

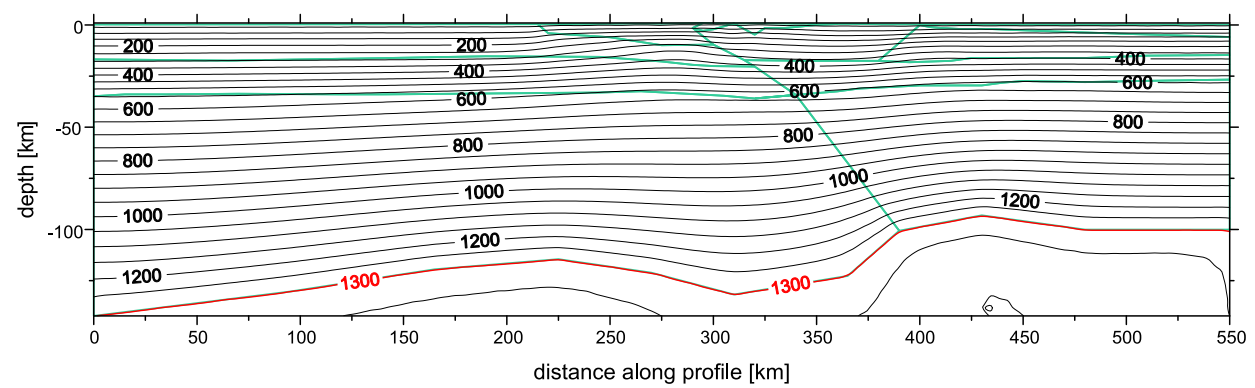

Fig. 3. Lithospheric temperature distribution calculated for transect IV, isoline values in ${ }^{\circ} \mathrm{C}$. The bottom of the model corresponds to the $1300{ }^{\circ} \mathrm{C}$ isotherm (red line). 
of the heat sources predominantly in the upper crust and background heat flow density from the lower mantle. The reliability of the temperature model usually depends on the accuracy and density of measurements of the surface heat flow density data but 2D integrated modelling algorithm ensures that our lithological model is constrained by calculation of free air anomaly and topography, which greatly increases the reliability of the model.

In the next step, the rheological parameters for every lithospheric unit of previously modelled transect IV has been assigned. These rheological parameters were carefully chosen based on the work of Carter and Tsenn (Carter and Tsenn, 1987) and Goetze and Evans (Goetze and Evans, 1979) and a previous rheological modelling in the Western Carpathians by Lankreijer et al. (1999). We made sure that the assigned rheological parameters for transect IV were also in correlation with our previous rheological modelling on transects I and II (Dérerová et al., 2012, 2014). These parameters are shown in Table 1a and Table $1 \mathrm{~b}$ together with densities and geothermal parameters of the 2D integrated lithospheric model of transect IV.

Table 1a. General properties used for calculation of rheological model.

\begin{tabular}{|l|c|c|}
\hline Definition & Parameter & Value \\
\hline Gravity acceleration $\left[\mathrm{ms}^{-2}\right]$ & $g$ & 9.81 \\
\hline Universal gas constant $\left[\mathrm{JmolK}^{-1}\right]$ & $R$ & 8.314 \\
\hline Temperature at the base of the lithosphere $\left[{ }^{\circ} \mathrm{C}\right]$ & $T_{m}$ & 1300 \\
\hline Static friction coefficient & $f_{s}$ & 0.6 \\
\hline Strain rate $\left[\mathrm{s}^{-1}\right]$ & $\dot{\varepsilon}$ & $10^{-15}$ \\
\hline Hydrostatic pore fluid factor & $\lambda$ & 0.35 \\
\hline
\end{tabular}

With the assigned parameters we were able to calculate the strength distribution in the lithosphere for studied transect. Fig. 4 shows vertically integrated compressional and extensional strength calculated along transect IV. Fig. 5 and Fig. 6 show the calculated yield strength contour plot for compressional and extensional deformation. In our calculations a strain rate $10^{-15} \mathrm{~s}^{-1}$ has been used because this value is commonly observed in compressional and extensional settings (Carter and Tsenn, 1987). We have calculated the strength envelopes for both compressional and extensional regimes in selected lithospheric columns of the model. We chose one column for each of the main tectonic units (European platform, the Western 
Table 1b. Thermal and rheological parameters used for modelling along transect IV (after Carter and Tsenn (1987) and Goetze and Evans (1979)). HP: heat production $\left[\mu \mathrm{Wm}^{-3}\right]$, TC: thermal conductivity $\left[\mathrm{Wm}^{-1} \mathrm{~K}^{-1}\right], \rho$ : density at room temperature $\left[\mathrm{kg} \mathrm{m}^{-3}\right], A_{p}$ : power law pre-exponential constant, $n$ : power law exponent, $E_{p}$ : power law activation energy $\left[\mathrm{kJ} \mathrm{mol}^{-1}\right]$.

\begin{tabular}{|c|l|c|c|c|c|c|c|}
\hline Nr. & Unit & HP & TC & $\boldsymbol{\rho}$ & $\boldsymbol{A}_{\boldsymbol{p}}$ & $\boldsymbol{n}$ & $\boldsymbol{E}_{\boldsymbol{p}}$ \\
\hline 1 & Neogene sediments & $2.5-3.0$ & 2.5 & $2400-2550$ & $3.16 \mathrm{E}-26$ & 3.30 & 186 \\
\hline 2 & Flysch and Volcanics & $1.0-2.5$ & $2.0-2.5$ & $2550-2650$ & $3.16 \mathrm{E}-26$ & 3.30 & 186 \\
\hline 3 & $\begin{array}{l}\text { Carpathian and Pannonian } \\
\text { upper crust }\end{array}$ & $3.0-3.5$ & 3.0 & 2750 & $3.16 \mathrm{E}-26$ & 3.30 & 186 \\
\hline $3 \mathrm{a}$ & $\begin{array}{l}\text { Inner Western Carpathian } \\
\text { upper crust }\end{array}$ & $2.0-2.5$ & 3.0 & 2750 & $3.16 \mathrm{E}-26$ & 3.30 & 186 \\
\hline 4 & European upper crust & $0.5-2.0$ & $2.5-3.0$ & $2750-2800$ & $3.16 \mathrm{E}-26$ & 3.30 & 186 \\
\hline 6 & European lower crust & 0.2 & 2.0 & 2960 & $6.31 \mathrm{E}-20$ & 3.05 & 276 \\
\hline 7 & $\begin{array}{l}\text { Carpathian and Pannonian } \\
\text { lower crust }\end{array}$ & 0.2 & 2.0 & 3000 & $6.31 \mathrm{E}-20$ & 3.05 & 276 \\
\hline 9 & Lower (mantle) lithosphere & 0.05 & 3.4 & 3325 & $7.94 \mathrm{E}-18$ & 4.50 & 535 \\
\hline
\end{tabular}

Carpathians and the Pannonian Basin). The strength distribution for given lithospheric columns is shown on Fig. 7.

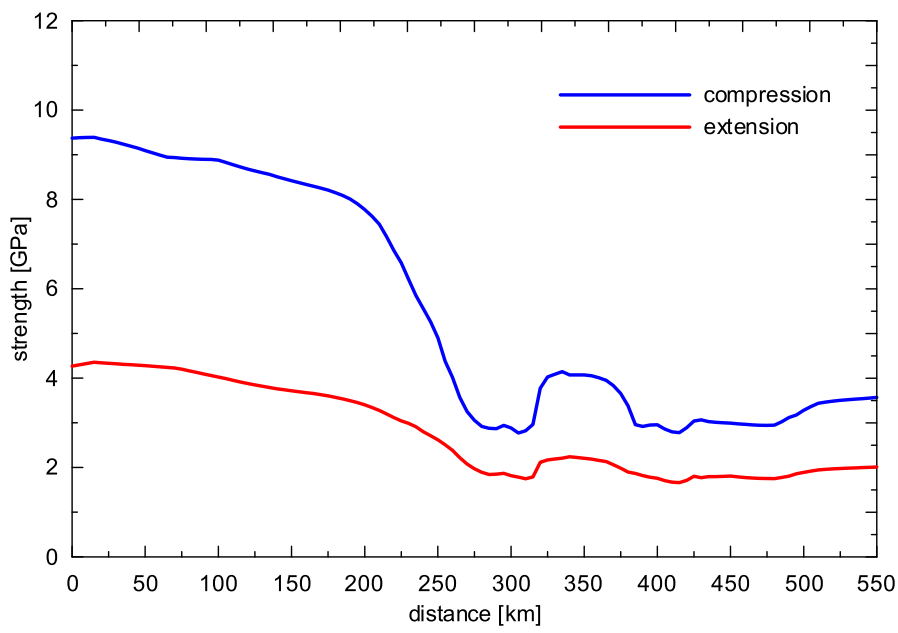

Fig. 4.Vertically integrated compressional (red line) and extensional (blue line) strength calculated along the transect IV. 

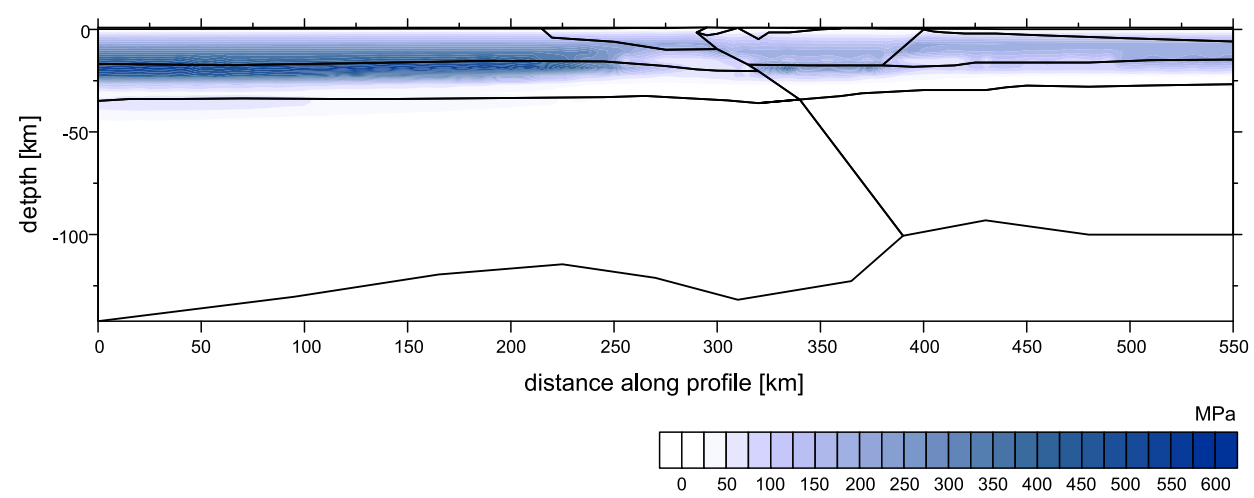

Fig. 5. Yield strength contour plot for compressional deformation calculated along transect IV calculated at a strain rate $10^{-15} \mathrm{~s}^{-1}$.
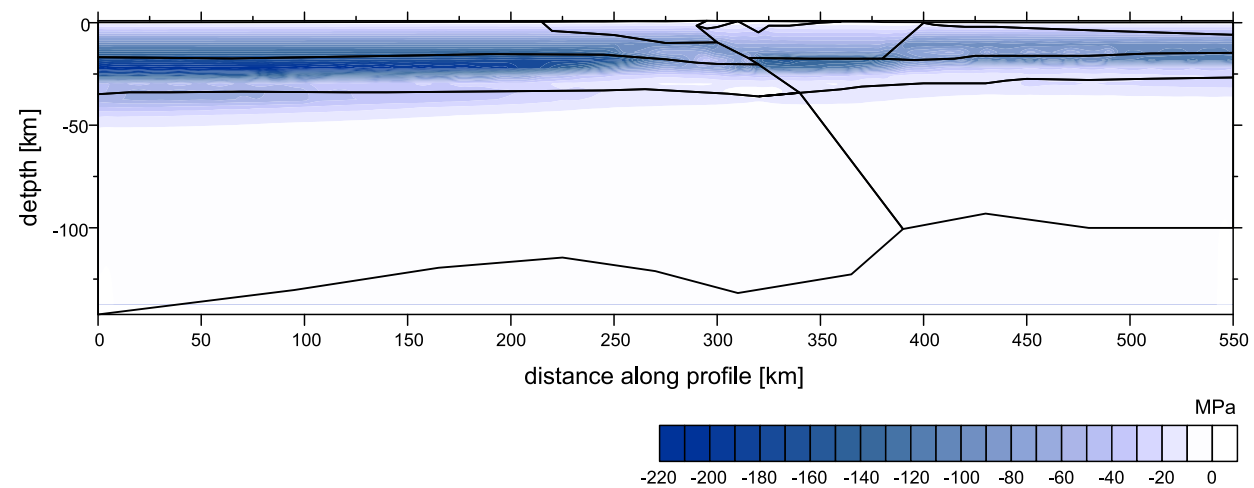

Fig. 6. Yield strength contour plot for extensional deformation calculated along transect IV calculated at a strain rate $10^{-15} \mathrm{~s}^{-1}$.

\section{Conclusions}

Based on the results related to the vertically integrated compressional and extensional strength along transect IV (Fig. 4), we can say that the lithospheric strength decreases from the European platform and the Western Carpathians to the Pannonian Basin. Decrease is more prominent in the case of compressional strength. A local increase in the values of strength can be observed in the eastern segment of the Western Carpathians where the lithospheric thickening occurs. This thickening (forming of a lithospheric root), which is interpreted as a small remnant of a subducted slab, is also 

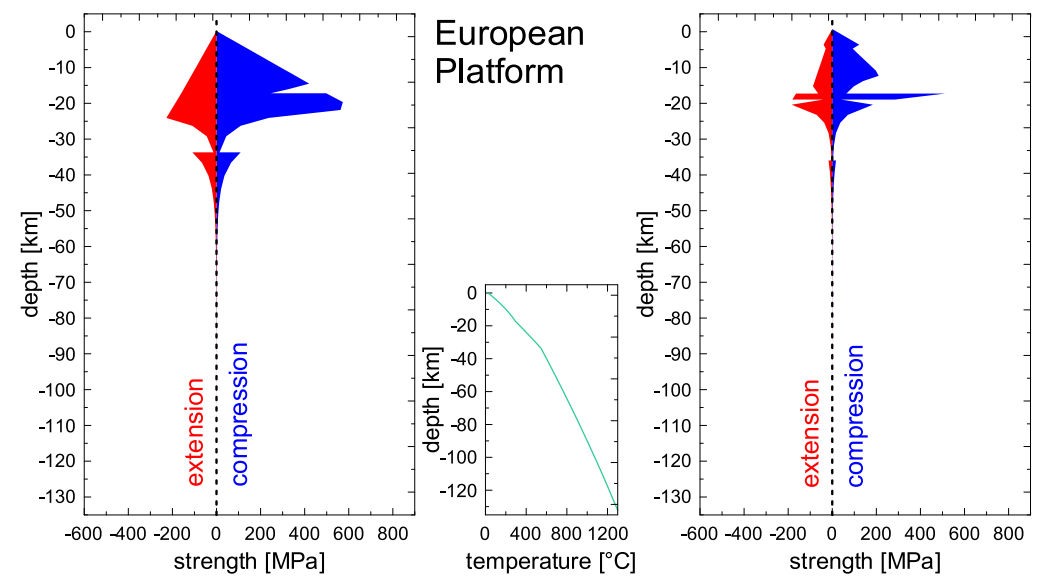

\section{Western Carpathians}
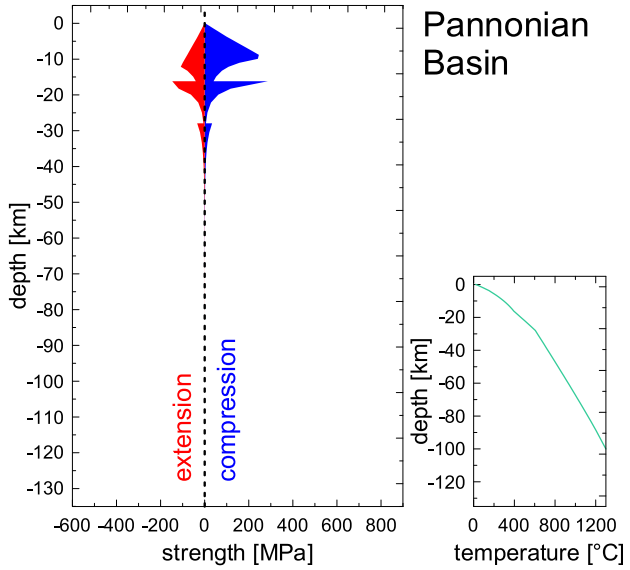

Fig. 7. Vertical strength distribution for different lithospheric columns calculated along transect IV. Negative and positive values correspond to extensional and compressional strength respectively.

accompanied by crustal thickening. If we look at the results of yield strength contour plot for compressional and extensional deformation (Figs. 5 and 6) and vertical strength distribution for different lithospheric columns (see the second strength envelope, where the column was chosen in the area of crustal and lithospheric thickening) for compressional and extensional deformation (Fig. 7), it shows that in the area of crustal thickening, the largest strength 
occurs on the boundary between upper and lower crust, causing the increase in the values that can be clearly seen on our calculated vertically integrated strength graph as an increase in both compressional (more prominent) and extensional strength. Along previously modelled transects I and II (Dérerová et al., 2012, 2014), where the lithosphere-asthenosphere boundary is almost flat and therefore no accompanying by crustal thickening is observed, the decrease in strength is slow and steady.

As general result, for all tectonic units (European platform, the Western Carpathians and the Pannonian basin), the largest strength occurs within the upper crust with its maxima on the boundary between upper and lower crust. Towards the lower crust, the strength significantly decreases. Within the uppermost mantle (lower lithosphere) the lithospheric strength almost disappears. These results suggest predominantly rigid deformation in the upper crust and ductile deformation (as a result of higher temperatures) in the lower part of the lithosphere. Similar results have been obtained in previously modelled transects I and II.

Acknowledgements. This research has been supported by the Slovak Grant Agency VEGA, grant No. 2/0006/19 and by the Slovak Research and Development Agency under grant APVV-16-0482, APVV-16-0146. Authors are grateful to Prof. Hermann Zeyen (Laboratoires IDES, Université Paris-Sud XI) for permission to use 2D integrated modelling software.

\section{References}

Ádám A., 1996: Regional magnetotelluric (MT) anisotropy in the Pannonian Basin (Hungary). Acta Geod. Geophys. Hung., 31, 1-2, 191-216.

Alasonati Tašárová Z., Afonso J. C., Bielik M., Götze H.-J., Hók J., 2009: The lithospheric structure of the Western Carpathian-Pannonian region based on the CELEBRATION 2000 seismic experiment and gravity modeling. Tectonophysics, $\mathbf{4 7 5}$, 3-4, 454-469, doi: 10.1016/j.tecto.2009.06.003.

Alasonati Tašárová Z., Fullea J., Bielik M., Oroda P., 2016: Lithospheric structure of Central Europe: Puzzle pieces from Pannonian Basin to Trans-European Suture Zone resolved by geophysical-petrological modelling. Tectonics, 35, 3, 722-753, doi : 10.1002/2015TC003935.

Bielik M., Makarenko I., Starostenko V., Legostaeva O., Dérerová J., Šefara J., Pašteka R., 2005: New 3D gravity modeling in the Carpathian-Pannonian basin region. Contrib. Geophys. Geod., 35, 1, 65-78. 
Bielik M., Kloska K., Meurers B., Švancara J., Wybraniec S. \& CELEBRATION 2000 Potential Field Working Group, 2006: Gravity anomaly map of the CELEBRATION 2000 region. Geol. Carpath., 57, 3, 145-156.

Bielik M., Striženec P., 1994: Flexure of the lithosphere beneath the Pannonian Basin. Contrib. Geophys. Geod., 24, 1, 87-104.

Bielik M., Ursíny M., 1997: Flexure of the elastic plate. Contrib. Geophys. Geod., 27, 1, 81-93.

Byerlee J., 1978: Friction of rocks. Pure Appl. Geophys., 116, 4-5, 615-626, doi: 10.1007 /BF00876528.

Carter N. L., Tsenn M. C., 1987: Flow properties of continental lithosphere. Tectonophysics, 136, 1-2, 27-63, doi : 10.1016/0040-1951(87)90333-7.

Čermák V., Král M., Krešl M., Kubík J., Šafanda J., 1991: Heat flow, regional geophysics and lithosphere structure in Czechoslovakia and adjacent part of Central Europe. In: Čermák V., Rybach L. (Eds.): Terrestrial heat flow and the lithosphere structure. Springer, Berlin, 133-165, doi: 10.1007/978-3-642-75582-8_6.

Csontos L., Nagymarosy A., Horváth F., Kováč M., 1992: Tertiary evolution of the IntraCarpathian area: A model. In: Ziegler P. A. (Ed.), Geodynamics of rifting, I, Tectonophysics, 208, 1-3, 221?241, doi: 10.1016/0040-1951(92)90346-8.

Dérerová J., Zeyen H., Bielik M., Salman K., 2006: Application of integrated geophysical modeling for determination of the continental lithospheric thermal structure in the eastern Carpathians. Tectonics, 25, 3, TC3009, doi: 10.1029/2005TC001883.

Dérerová J., Kohút I., Bielik M., Bošanský M., Porubčanová B., 2012: Calculation of temperature distribution and rheological properties of the lithosphere along transect I in the Western Carpathians. Contrib. Geophys. Geod., 42, 4, 345-356, doi: 10.2478/v10126-012-0016-5.

Dérerová J., Bielik M., Pašiaková M., Kohút I., Hlavňová P., 2014: Calculation of temperature distribution and rheological properties of the lithosphere along transect II in the Western Carpathians. Contrib. Geophys. Geod., 44, 2, 149-160, doi: $10.2478 /$ con geo-2014-0009.

Goetze C., Evans B., 1979: Stress and temperature in the bending lithosphere as constrained by experimental rocks mechanics. Geophys. J. Int., 59, 3, 463-478, doi: 10 $.1111 / j .1365-246 X .1979 . t b 02567 . x$.

Grad M., Guterch A., Keller G. R., Janik T., Hegeds E., Vozár J., Ol1czka A., Tiira T., Yliniemi J., 2006: Lithospheric structure beneath trans-Carpathian transect from Precambrian platform to Pannonian Basin: CELEBRATION 2000 seismic profile CEL05. J. Geophys. Res., 111, B3, B03301, doi: 10.1029/2005JB003647.

Grinč M., Zeyen H., Bielik M., Plašienka D., 2013: Lithospheric structure in Central Europe: Integrated geophysical modelling. J. Geodyn., 66, 13-24, doi: 10.1016/j.jog .2012 .12 .007 .

Horváth F., 1993: Towards a mechanical model for the formation of the Panonian basin. Tectonophysics, 226, 1-4, 333?357, doi: 10.1016/0040-1951(93)90126-5.

Hrubcová P., Oroda P., Grad M., Geissler W. H., Guterch A., Vozár J., Hegeds E., Sudetes Working Group, 2010: From the Variscan to the Alpine Orogeny: crustal structure 
of the Bohemian Massif and the Western Carpathians in the light of the SUDETES 2003 seismic data. Geophys. J. Int., 183, 2, 611-633, doi: 10.1111/j.1365-246X. 20 10.04766.x.

Lachenbruch A. H., Sass J. H., 1977: Heat flow in the United States and the thermal regime of the crust. In: Heacock J. G., Keller G. V., Oliver J. E., Simmons G.: The Earth's crust. Geophys. Monogr. Ser., 20, 626?675, Washington, D.C., doi: 10.1029/GM020p0626.

Lankreijer A., Bielik M., Cloetingh S., Majcin D., 1999: Rheology predictions across the Western Carpathians, Bohemian Massif and the Pannonian Basin: implications for tectonic scenarios. Tectonics, 18, 6, 1139-1153, doi: 10.1029/1999TC900023.

Lynch H. D., Morgan P., 1987: The tensile strength of the lithosphere and the localisation of extension. In: Coward M. P., Dewey J. F., Hancock P. L. (Eds.): Continental Extension Tectonics. Geol. Soc. Spec. Publ., London, 28, 1, 53-65, doi: 10.1144/GSL.SP.1987.028.01.05.

Majcin D., 1993: Thermal state of the West Carpathian lithosphere. Stud. Geophys. Geod., 37, 4, 345-364, doi: 10.1007/BF01613581.

Mayerová M., Novotný M., Fejfar M., 1994: Deep seismic sounding in Czechoslovakia. In: Bucha V., Blížkovský M. (Eds.): Crustal structure of the Bohemian Massif and the West Carpathians. Academia Press, Springer Verlag, 13-20.

Putiška R., Dostál I., Kušnirák D., 2012a: Determination of dipping contacts using electrical resistivity tomography. Contrib. Geophys. Geod., 42, 2, 161180, doi: 10.2478/ v10126-012-0007-6.

Putiška R., Nikolaj M., Dostál I., Kušnirák D., 2012b: Determination of cavities using electrical resistivity tomography. Contrib. Geophys. Geod., 42, 2, 201211, doi: 10.2478/v10126-012-0018-3.

Ratschbacher L., Merle O., Davy P., Cobbold P., 1991a: Lateral extrusion in the eastern Alps, Part 1: Boundary conditions and experiments scaled for gravity. Tectonics, 10, 2, 245?256, doi: 10.1029/90TC02622.

Ratschbacher L., Frisch W., Linzer H.-G., Merle O., 1991b: Lateral extrusion in the eastern Alps, Part 2: Structural analysis. Tectonics, 10, 2, 257?271, doi : 10.1029/90TC 02623.

Tomek E., Ibrmajer I., Koráb T., Biely A., Dvooáková L., Lexa J., Zbooil A., 1989: Crustal structures of the West Carpathians on deep reflection seismic line 2T. Mineralia Slovaca, 21, 1, 3-26 (in Slovak with English summary).

Vozár J., Šantavý J., (Eds.) 1999: Atlas of deep reflection seismic profiles of the Western Carpathians and their interpretation (Atlas hlbinných reflexných seizmických profilov Západnych Karpát a ich interpretácia). Ministry of Environment of the Slovak Republic, Bratislava, ISBN 80-88974-06-2, 76 p.

Zahorec P., Papčo J., Marušiak I., Mikuška J., Pašteka R., Ferianc D., Majkráková M., 2013: Reconstruction of the gravity acceleration from complete Bouguer anomalies in Slovakia - modern software solution. In: Nové poznatky z realizácie a interpretácie geodetických meraní. Zborník referátov. Slovenská spoločnost' geodetov a kartografov, Bratislava, 75-83. 
Zeyen H., Fernàndez M., 1994: Integrated lithospheric modeling combining thermal, gravity and local isostasy analysis: Application to the NE Spanish Geotransect. J. Geophys. Res., 99, B9, 18089-18102, doi: 10.1029/94JB00898.

Zeyen H., Dérerová J., Bielik M., 2002: Determination of the continental lithosphere thermal structure in the western Carpathians: Integrated modelling of surface heat flow, gravity anomalies and topography. Phys. Earth Planet. Inter., 134, 1-2, 89 104, doi : 10.1016/S0031-9201(02)00155-3. 